\title{
Cytaty z pieśni o Słudze Jahwe w Ewangeliach synoptycznych
}

Księgi Izajasza nie można przypisać jednemu autorowi. Można w niej wyodrębnić trzy części. Z prorokiem z ósmego wieku przed Chrystusem łączy się tylko pierwsza część Księgi, czyli rozdziały 1-39. Nazwano ją Księgą Proto-Izajasza ${ }^{1}$. Drugą część, obejmującą rozdziały 40-55, łączy się współcześnie z innym prorokiem, zwanym Deutero-Izajaszem. Żył on w czasie niewoli babilońskiej². Trzecia część, rozdziały 56-66, przypisuje się nieznanemu prorokowi z okresu perskiego. Nazwano go Trito-Izajaszem³.

Pieśni o Słudze Jahwe to cztery fragmenty, które znajdują się w drugiej części Księgi Izajasza (42, 1-9; 49, 1-7; 50, 4-9; 52, 13-53, 12). Działalność

${ }^{1}$ Por. L. Stachowiak, Geneza Księgi Izajasza 1-39, „Roczniki Teologiczne” 1 (1996), s. 43-53; A. Salas, Prorocy. Zwiastuni Boga żywego, Częstochowa 1999, s. 75nn.

${ }^{2}$ Por. J. S. Synowiec, Oto twój król przychodzi. Mesjasz w pismach Starego Przymierza, Kraków 1992, s. 126n; tenże, Prorocy Izraela, ich pisma i nauka, Kraków 1995, s. 154nn, 261nn; S. Gądecki, Wstęp do Ksiag prorockich Starego Testamentu, Gniezno 1993, s. 167nn; H. Langkammer, Historia czasów Starego i Nowego Testamentu, Wrocław 1995, s. 38n; G. Witaszek, Pieśni Sługi Jahwe (Iz 42, 1-7; 49, 1-7; 50, 4-9; 52, 13-53, 12), [w:] Homo meditans XIX: „Do kogóż pójdziemy? Ty masz słowa życia wiecznego”, red. J. Misiurek, A. J. Nowak, W. Słomka, Lublin 1998, s. 117n; A. Salas, Prorocy. Zwiastuni Boga żywego, s. 125nn; R. Rumianek, Prorocy okresu niewoli babilońskiej, Warszawa 2004, s. 179nn.

${ }^{3}$ Por. A. Läpple, Od Księgi Rodzaju do Ewangelii, Kraków 1983, s. 322; T. Jelonek, Prorocy Starego Testamentu, Kraków 1993, s. 60nn; J. S. Synowiec, Prorocy Izraela, ich pisma inauka, dz. cyt., s. 303; L. Stachowiak, Księga Izajasza I. 1-39. Wstęp - przekład z oryginału - komentarz, Poznań 1996, s. 5; tenże, Księga Izajasza II-III. Wstęp-przekład z oryginału - komentarz - Ekskursy, Poznań 1996, s. 24nn, 47nn; A. Salas, Prorocy. Zwiastuni Boga żywego, dz. cyt., s. 147n; D. Adamczyk, Starotestamentalne cytaty w Ewangelii według świętego Mateusza i ich zastosowanie w aktualnych polskich podręcznikach do katechizacji. Studium biblijno-katechetyczne, Kielce 2006, s. 137. 
proroka Deutero-Izajasza przypada na okres między zburzeniem Jerozolimy w 586 roku przed narodzeniem Chrystusa a zajęciem Babilonu przez króla perskiego Cyrusa w roku 538. Jego działalność przypada na okres wygnania. Głosił on ludziom w niewoli babilońskiej orędzie pocieszenia. W Księdze Deutero-Izajasza oprócz zasadniczej części $(40,12-55,9)$ można wyróżnić wstęp $(40,1-11)$ i zakończenie $(55,10-13)$. W rozdziałach 40-48 zawarta jest zapowiedź bliskiego wyzwolenia z niewoli babilońskiej. Natomiast rozdziały 49-55 dotyczą odbudowy Syjonu4.

Pieśni o Słudze Jahwe należą do najtrudniejszych w całej księdze. Nasuwają problemy natury literackiej, krytycznej i egzegetycznej. Kompozycja literacka i jedność czterech pieśni o cierpiącym Słudze Jahwe nastręczają znaczne trudności. Trudno także o jednoznaczną odpowiedź, kim jest postać Sługi Bożego. Określenie 'ebed Jahwe jest znane w Starym Testamencie już z czasów przed niewolą babilońską. Jest to określenie pełne pokory, a jednocześnie zaszczytny tytuł, którym Bóg określa wybitne postacie: Abrahama (Rdz 26, 24), Mojżesza (Wj 14, 31) czy Dawida (2 Sm 7, 8)5.

Z treści tych pieśni nie dowiadujemy się, kim jest ów Sługa Jahwe. Zagadnienie to pozostaje ciągle otwarte. Postać Sługi Jahwe może mieć sens indywidualny lub zbiorowy. W sensie indywidualnym chodzi o jakąś postać historyczną lub ponadhistoryczną. Natomiast w sensie zbiorowym SługąJahwe jest cały naród Boży lub wybrana jego część ${ }^{6}$. Pomijając te trudności interpretacyjne, $w$ czterech pieśniach o Słudze Jahwe zawarty jest obraz jego misji. Ma ona charakter szczególny i uniwersalny. Sługa

${ }^{4}$ Por. S. Gądecki, Wstęp do ksiag prorockich Starego Testamentu, dz. cyt., s. 171; R. Rumianek, Prorocy okresu niewoli babilońskiej, dz. cyt., s. 180n.

${ }^{5}$ Por. L. Stachowiak, Księga Izajasza II-III..., dz. cyt., s. 97n; E. Zawiszewski, Księgi proroków. Wstęp szczegółowy i analiza wybranych fragmentów, Pelplin 1995, s. 98nn; R. Rumianek, Prorocy okresu niewoli babilońskiej, dz. cyt., s. 185.

${ }^{6}$ Por. S. Gądecki, Wstęp do Ksiagg prorockich Starego Testamentu, dz. cyt., s. 173n; E. Beck, Sługa Pański, [w:] Praktyczny słownik biblijny, red. A. Grabner-Haider, Warszawa 1994, kol. 1211n; J. S. Synowiec, Oto twój król przychodzi..., dz. cyt., s. 145; L. Stachowiak, Księga Izajasza II-III..., dz. cyt., s. 343; E. Zawiszewski, Księgi proroków..., s. 99n; G. Witaszek, Pieśni Stugi Jahwe (Iz 42,1-7; 49,1-7; 50,4-9; 52,13-53,12), s. 125n; C. Stuhlmueller, Deutero-Izajasz (Iz 40-55), [w:] Katolicki komentarz biblijny, red. R. E. Brown, J. A. Fitzmyer, R. E. Murphy, Warszawa 2001, s. 646n; J. Lemański, Cierpienia ,stugi Boga” typem zbawczej Pasji Chrystusa, „Verbum Vitae” 1 (2002), s. 76n; R. Rumianek, Prorocy okresu niewoli babilońskiej, dz. cyt., s. 185; W. Pikor, Izajaszowy Sługa Jahwe a nowe przymierze. Analiza kontekstualna Iz 42, 1-9, „Zeszyty Naukowe KUL” 2 (2006), s. 24n. 
Jahwe będzie ustalał prawo Boże na ziemi. Musi wiele wycierpieć, a nawet poniesie śmierć. W utworach tych znajdują się także pewne oznaki, że postać ta powstanie z martwych. Dopiero jednak w świetle Nowego Testamentu można odczytać pełniejszy sens zapowiedzi dotyczących Sługi Jahwe. Autorzy Nowego Testamentu w Izajaszowym Słudze Jahwe widzą zapowiedź proroczą i typ samego Jezusa Chrystusa, Mesjasza i Zbawiciela. Potwierdza to sam Jezus Chrystus (Łk 22, 37; J 1, 29; Dz 8, 35). Jednakże w Nowym Testamencie znajdują się także teksty, które Sługę Jahwe dostrzegają w uczniach Jezusa (Mt 5, 14.16.39), w świętym Pawle (Dz 13, 47), a także w samym ludzie izraelskim $(€ k$ 1, 54)7.

W pierwszej pieśni o Słudze Jahwe została podkreślona rola pośrednictwa Sługi Bożego. To On przyniesie narodom Prawo. Jest to rodzaj mandatu misyjnego. Bóg przedstawia swojego wybranego. Dotyczy to zwłaszcza jego powołania, które ma polegać na umocnieniu religii ${ }^{8}$. W drugiej pieśni Sługa sam mówi o swoim powołaniu, o trudnościach w jego wypełnieniu oraz o nawracaniu pogan. $W$ trzeciej pieśni Sługa podkreśla swoją gorliwość. Mówi o trudnościach, ale wyraża ufność w pomoc Boga. Czwarta pieśn ukazuje jego cierpienie i śmierć. Miało się to dokonać dla zbawienia ludzi ${ }^{9}$. W Ewangeliach synoptycznych zawarte są cytaty z pierwszej i czwartej pieśni o Słudze Jahwe.

\section{Łagodny Sługa Jahwe (Iz 42, 1-4 i Mt 12, 18-21)}

Słowa o łagodnym Słudze Jahwe zamieszcza spośród synoptyków tylko Mateusz. Cytat dotyczy słów z Iz 42, 1-4: „Oto mój Sługa, którego podtrzymuję. Wybrany mój, w którym mam upodobanie. Sprawiłem, że Duch mój na Nim spoczął; On przyniesie narodom Prawo. Nie będzie wołał ni podnosił głosu, nie da słyszeć krzyku swego na dworze. Nie złamie trzciny nadłamanej, nie zagasi knotka o nikłym płomyku. On niezachwia-

${ }^{7}$ Por. S. Gądecki, Wstęp do ksiag prorockich Starego Testamentu, dz. cyt., s. 174; R. Rumianek, Prorocy okresu niewoli babilońskiej, dz. cyt., s. 185n; D. Adamczyk, Starotestamentalne cytaty w Ewangelii według świętego Mateusza..., dz. cyt., s. 152; S. Mędala, Dobra Nowina (Wprowadzenie ogólne do Ewangelii synoptycznych), [w:] Ewangelie synoptyczne, red. J. Frankowski, Warszawa 2006, s. 136n (Wprowadzenie w Myśl i Wezwanie Ksiąg Biblijnych, 8).

${ }^{8}$ Por. H. Langkammer, Teologia biblijna Starego i Nowego Testamentu, Legnica 2007, s. 189n.

${ }^{9}$ Por. S. Mędala, Dobra Nowina (Wprowadzenie ogólne do Ewangelii synoptycznych), dz. cyt., s. 133n; R. Rumianek, Prorocy okresu niewoli babilońskiej, dz. cyt., s. 186. 
nie przyniesie Prawo. Nie zniechęci się ani nie załamie, aż utrwali Prawo na ziemi, a Jego pouczenia wyczekują wyspy”. W Księdze Izajasza słowa te znajdują się w ramach pierwszej pieśni o Słudze Jahwe (Iz 42, 1-9).

Myśl przewodnia tego fragmentu dotyczy ugruntowania prawa Bożego na ziemi. Ma tego dokonać Sługa Jahwe. Jest to wypowiedź Boga o swoim Słudze. Jahwe kieruje te słowa do słuchaczy. W ten sposób przedstawia swojego Sługę. Wyrażenie „mój sługa” w Starym Testamencie miało znaczenie bardzo pochlebne. Jahwe zaznacza, że ma upodobanie w swoim Słudze i nazywa go swoim wybranym. Dokonuje tej prezentacji Sługi w sposób uroczysty. Z treści Iz 42, 1-4 dowiadujemy się, że Sługa jest wybrańcem i ulubieńcem Jahwe. Bóg podtrzymuje swojego Sługę. Oznacza to, że opiekuje się nim, aby ten mógł wypełnić wyznaczone mu zadania. O jego mocy świadczą słowa Jahwe, który zapewnia, że położył na nim swojego Ducha (por. Iz 42, 1). Bóg wyposażył go w swojego Ducha i okazuje mu wsparcie. Taka moc towarzyszyła sędziom, królom i prorokom. Dzięki tej mocy miało nastąpić odrodzenie narodu ${ }^{10}$.

Sługa ma do spełnienia określone zadanie. Ma ogłaszać i rozpowszechniać prawo Boże. Odnosi się to nie tylko do narodu izraelskiego, ale i do narodów pogańskich. Zadaniem Sługi Jahwe jest pouczanie narodów dotyczące postępowania człowieka. Wydawanie pouczeń należało do kompetencji kapłanów i proroków. Jego słów pouczenia oczekują wyspy. Chodzi tu o kraje pogańskie. Wynika stąd, że prawo, jakie zaniesie im Sługa Jahwe, nie będzie dla nich ciężarem. Ludzie oczekują na te pouczenia i potrzebują ich. Będzie to dla nich stanowić cenną wartość (por. Iz 42, 1. 4). Sługa przywróci sprawiedliwy porządek. Prawo Boże, które dotąd było własnością samego Izraela, zostanie dane innym narodom ${ }^{11}$.

${ }^{10}$ Por. A. Kowalczyk, Motywy zmian w Mateuszowych cytatach Starego Testamentu niezgodmych z tekstem masoreckim i Septuaginta, „Studia Gdańskie” 8 (1992), s. 7n; J. S. Synowiec, Oto twój król przychodzi..., dz. cyt., s. 147nn; T. Brzegowy, Prorocy Izraela, Tarnów 1994, s. 179; E. Zawiszewski, Księgi proroków..., dz. cyt., s. 99; L. Stachowiak, Księga Izajasza II-III..., dz. cyt., s. 99n; G. Witaszek, Pieśni Sługi Jahwe (Iz 42, 1-7; 49, 1-7; 50, 4-9; 52, 13-53, 12), dz. cyt., s. 119; Międzynarodowy komentarz do Pisma Świętego, red. W. Chrostowski, Warszawa 2000, s. 870; R. Rumianek, Prorocy okresu niewoli babilońskiej, dz. cyt., s. 186n; D. Adamczyk, Starotestamentalne cytaty w Ewangelii według świętego Mateusza..., dz. cyt., s. 151.

${ }^{11}$ Por. J. S. Synowiec, Oto twój król przychodzi..., dz. cyt., s. 140nn; tenże, Prorocy Izraela, ich pisma i nauka, dz. cyt., s. 290n; G. Witaszek, Pieśni Sługi Jahwe (Iz 42, 1-7; 49, 1-7; 
Sługa ma działać z wyjątkową delikatnością, cichością i wytrwałością. Będzie występował z wielką pokorą. Z treści Iz 42, 2 wynika, że ów Sługa nie będzie krzyczał, nie będzie stosował siły wobec słabych. Jego postawa będzie pełna łagodności. Nie będzie usiłował zastraszyć swoich słuchaczy. Te cechy autor kryje pod obrazami niezgniecionej trzciny i knotka o nikłym płomyku (por. w. 3). Celem misji Sługi nie jest niszczenie, lecz ocalenie tego, co ma jeszcze możliwość przeżycia. Sługa będzie więc łagodny w swoim działaniu, w szczególności w odniesieniu do słabych. Bóg przymierza będzie Bogiem miłosierdzia i przebaczenia. Ludzką słabość Sługa napełni mocą. Inną ważną cechą Sługi Jahwe będzie Jego niezłomność. Nie zniechęci się pomimo trudności. Doprowadzi do tego, aby Boże prawo, dotychczasowa własność Izraela, dotarło do pogan (por. w. 4). Sługa Jahwe ma spełniać rolę herolda Bożego i głosić wszystkim narodom posłannictwo o zbawieniu ${ }^{12}$.

W wersetach 5-6 następuje rozwinięcie myśli historiozbawczej. Sługa Jahwe stanie się „światłością dla narodów” (w. 6b). Owa myśl zostaje rozwinięta w wersecie 7: ,abyś otworzył oczy niewidomym, ażebyś z zamknięcia wypuścił jeńców, z więzienia tych, co mieszkają w ciemności". Jest to zapowiedź o charakterze przyszłościowym. Potwierdza to treść wersetu 9: „Pierwsze wydarzenia oto już nadeszły, nowe zaś Ja zapowiadam, zanim się rozwiną, już wam je ogłaszam"13.

50, 4-9; 52, 13-53, 12), s. 119; R. Rumianek, Prorocy okresu niewoli babilońskiej, dz. cyt., s. 187; D. Adamczyk, Starotestamentalne cytaty w Ewangelii według świętego Mateusza..., dz. cyt., s. 146; H. Langkammer, Teologia biblijna Starego i Nowego Testamentu, dz. cyt., s. 189.

${ }^{12}$ Por. T. Brzegowy, Prorocy Izraela, dz. cyt., s. 181;J. S. Synowiec, Oto twój król przychodzi..., dz. cyt., s. 149n; tenże, Prorocy Izraela, ich pisma i nauka, dz. cyt., s. 291; L. Stachowiak, Ksiegga Izajasza II-III..., dz. cyt., s. 100n; E. Zawiszewski, Księgi proroków..., dz. cyt., s. 100; S. Potocki, Wybrane zagadnienia zhistorii zbawienia Starego Testamentu. Studium katechetyczne, Przemyśl 1999, s. 189nn; Międzynarodowy komentarz do Pisma Świętego, s. 872; C. Stuhlmueller, Deutero-Izajasz (Iz 40-55), [w:] Katolicki komentarz biblijny, dz. cyt., s. 647; R. Rumianek, Prorocy okresu niewoli babilońskiej, dz. cyt., s. 187; D. Adamczyk, Starotestamentalne cytaty w Ewangelii według świętego Mateusza..., dz. cyt., s. 151n; W. Pikor, Izajaszowy Sługa Jahwe a nowe przymierze..., dz. cyt., s. 24n; H. Langkammer, Teologia biblijna Starego i Nowego Testamentu, dz. cyt., s. 189.

${ }^{13}$ Por. E. Zawiszewski, Księgi proroków..., dz. cyt., s. 102nn; G. Witaszek, Pieśni Sługi Jahwe (Iz 42, 1-7; 49, 1-7; 50, 4-9; 52, 13-53, 12), dz. cyt., s. 120; Międzynarodowy komentarz do Pisma Świętego, dz. cyt., s. 872; H. Langkammer, Teologia biblijna Starego i Nowego Testamentu, dz. cyt., s. 189. 
Synoptycy odnoszą to proroctwo do Jezusa (Mt 3, 13-17; Mk 1, 11; Łk 3, 22). W Ewangeliach następuje tylko zmiana rzeczownika „Sługa” na „Syn”. Motyw światła podejmuje zaś św. Jan. Odnosi go do Chrystusa, którego nazywa „światłością świata” $(\mathrm{J} 8,12)^{14}$. Cytat z Iz 42, 1-4 znajdujemy w Mt 12, 18-21: „Oto mój Sługa, którego wybrałem; Umiłowany mój, w którym moje serce ma upodobanie. Położę ducha mojego na Nim, a On zapowie prawo narodom. Nie będzie się spierał ani krzyczał, i nikt nie usłyszy na ulicach Jego głosu. Trzciny zgniecionej nie złamie ani knota tlejącego nie dogasi, aż zwycięsko sąd przeprowadzi. W Jego imieniu narody nadzieję pokładać będą"15.

Mateusz umieszcza te słowa po relacji o uzdrowieniu w szabat (por. Mt 12, 9-14). Po tym wydarzeniu faryzeusze chcą pojmać Jezusa. Jezus jednak nie pozwala się pojmać, ponieważ nie nadeszła jeszcze Jego godzina. Dowiedziawszy się o zamiarach faryzeuszy, oddala się stamtąd (w. 15a). Idzie za Nim wielu chorych, których uzdrawia (w. 15b). Jednocześnie nie pozwala na to, aby były rozgłaszane cuda przez Niego czynione. Mateusz podkreśla, że Jezus surowo tego zabrania (w. 16). Nie chce, aby postrzegano Go wyłącznie jako ziemskiego uzdrowiciela. Jezus pragnie, aby widziano w Jego życiu i posłudze urzeczywistnienie proroctwa z Księgi Izajasza o cierpiącym Słudze Jahwe. Tak rozumie to Ewangelista, cytując w tym miejscu dłuższy fragment $\mathrm{z}$ tej starotestamentowej księgi ${ }^{16}$.

W przekonaniu Mateusza to Jezus jest cierpiącym Sługą Jahwe wybranym przez Boga i umiłowanym. To w Nim Bóg sobie upodobał.Jezus, na którym spocznie Duch Boży, ogłosi narodom nowe prawo. Cała Jego

${ }^{14}$ Por. H. Langkammer, Teologia biblijna Starego i Nowego Testamentu, dz. cyt., s. 189.

${ }^{15}$ Por. C. L. Blomberg, Matthew, [w:] Commentary on the New Testament Use of the Old Testament, red. G. K. Beale, D. A. Carson, Grand Rapids 2007, s. 42nn.

${ }^{16}$ Por. J. Schmid, L'Evangelo secondo Matteo, Brescia 1976, s. 275n; J. Homerski, Ewangelia według świętego Mateusza. Wstęp - przekład zoryginału-komentarz, Poznań-Warszawa 1979, s. 206; O. da Spinetoli, Matteo. Il vangelo della chiesa, Assisi 1983, s. 358nn; S. Grasso, Il Vangelo di Matteo, Roma 1995, s. 312n; K. Romaniuk, A. Jankowski, L. Stachowiak, Komentarz praktyczny do Nowego Testamentu, t. 1, Poznań-Kraków 1999, s. 75; Międzynarodowy komentarz do Pisma Świętego, dz. cyt., s. 1172; A. Paciorek, Ewangelia według świętego Mateusza, rozdziały 1-13, Wstęp - przekład z oryginału - komentarz, Częstochowa 2005, s. 499n; D. Adamczyk, Starotestamentalne cytaty w Ewangelii według świętego Mateusza..., dz. cyt., s. 152; C. L. Blomberg, Matthew, [w:] Commentary on the New Testament Use of the Old Testament, dz. cyt., s. 42. 
działalność będzie nacechowana dobroczynnością. Sława doczesna ani rozgłos nie będą głównymi motywami Jego działania. Nie będzie prowadził sporów. Nie będzie krzyczał. Jego cechą charakterystyczną będzie łagodność i dobroć. Nadejdzie jednak chwila dokonania sprawiedliwości. Będzie to czas pełnego tryumfu Jezusa. Narody będą pokładać nadzieję w Jego imieniu ${ }^{17}$.

Cytat z Iz 42, 1-4 w Ewangelii Mateusza jest uwypukleniem powołania Jezusa przez Boga i Jego misji. Ta misja polega na głoszeniu zbawienia narodom pogańskim. Nie jest to waleczny Mesjasz, na którego wielu oczekiwało. Łagodność Jezusa doprowadzi Jego misję do szczęśliwego końca.Jezus jest tu przedstawiony jako Zbawiciel wszystkich narodów. Mateusz zgodnie z założeniem swojej Ewangelii ukazuje uniwersalizm królestwa Bożego. Wskazuje też na cechy uniwersalizmu posłannictwa Mesjasza-Jezusa' ${ }^{10}$.

\section{Obarczony naszymi słabościami (Iz 53, 4 i Mt 8, 17)}

Kolejny tekst z Księgi Izajasza, który wykorzystuje tylko Mateusz, to słowa z Iz 53, 4: ,Lecz On się obarczył naszym cierpieniem, On dźwigał nasze boleści". Są to słowa z czwartej pieśni Sługi Pańskiego, która dotyczy Jego cierpienia, śmierci i chwały (por. Iz 52, 13-53, 12).

Treść czwartej pieśni o Słudze Jahwe nawiązuje do tematu cierpienia zawartego w poprzedniej pieśni. Fragment ten jest dialogiem między Jahwe a wspólnotą Izraela. Autor natchniony wylicza najpierw prerogatywy Sługi. Skupiają się one wokół motywu wywyższenia. Bóg przedstawia ziemską drogę Sługi i zapowiada jego wywyższenie określone aż przez cztery terminy: „powiedzie się", „wybije się”, „wywyższy”, „wyrośnie bardzo" (Iz 52,13). Będzie to zatem najpełniejsze wywyższe-

${ }^{17}$ Por. J. S. Synowiec, Oto twój król przychodzi..., dz. cyt., s. 251; K. Romaniuk, A. Jankowski, L. Stachowiak, Komentarz praktyczny do Nowego Testamentu, dz. cyt., t. 1, s. 75n; D. Adamczyk, Starotestamentalne cytaty w Ewangelii według świętego Mateusza..., dz. cyt., s. 152n.

${ }^{18}$ Por. W. Trilling, Vangelo secondo Matteo, t. 1, Roma 1968, s. 235nn; J. Schniewind, Il Vangelo secondo Matteo, Brescia 1977, s. 279n; J. Homerski, Ewangelia według świętego Mateusza..., dz. cyt., s. 206; R. Fabris, Matteo, Roma 1982, s. 274n; A. Sand, Das Evangelium nach Matthäus, Regensburg 1986, s. 258nn; J. Radermakers, Lettura pastorale del vangelo di Matteo, Bologna 1997, s. 205; S. Fausti, Una comunità legge il Vangelo di Matteo, t. 1 (113), Bologna 1999, s. 229nn; D. Adamczyk, Starotestamentalne cytaty w Ewangelii według świętego Mateusza..., dz. cyt., s. 153. 
nie. Dalej następuje przejście do motywu uniżenia. Owo wywyższenie będzie konsekwencją wielkiego upokorzenia Sługi: „Nieludzko został oszpecony Jego wygląd i postać Jego była niepodobna do ludzi” (w. 14). Mimo, że będzie bardzo oszpecony i sponiewierany, to wzbudzi on podziw wśród narodów i ich władców (52,13-15). W wersecie 15 zawarta jest wzmianka o powszechnym niezrozumieniu tajemnicy cierpienia ${ }^{19}$. Środkowa część pieśni $(53,1-11 b)$ to zbiorowa lamentacja nad losami Sługi Jahwe. Wspólnota Izraela podnosi lament nad jego cierpieniami, które zniósł on z niezwykłą równowagą ducha ${ }^{20}$. Ta część zawiera opis zdumienia, które wyrażają pytania retoryczne: „Któżuwierzy temu, cośmy usłyszeli? Na kimże się ramię Pańskie objawiło?" (w. 1). Jednak społeczność ludu Bożego dostrzega w Słudze spełnienie się Bożych zamiarów. Mogą je przysłonić zewnętrzne znaki Sługi (w. 2). Sługa został najpierw zlekceważony i wzgardzony przez ludzi. Stał się symbolem cierpienia. Określenie „mąż boleści” (53,3) wskazuje na człowieka, z którego naturą związane jest cierpienie. Ta sama myśl jest uwypuklona przez metaforę zakrywania twarzy, aby nie patrzeć na cierpienie Sługi. Ci, który patrzą, uważają go za przeklętego przez Boga i pogardzają Nim²1.

${ }^{19}$ Por. M. Peter, Wykład Pisma Świętego Starego Testamentu, Poznań-Warszawa 1978, s.555; J. S. Synowiec, Oto twój król przychodzi..., dz. cyt., s. 160nn; tenże, Prorocy Izraela, ich pisma i nauka, dz. cyt., s. 296; T. Brzegowy, Prorocy Izraela, dz. cyt., s. 186n; E. Zawiszewski, Księgi proroków..., dz. cyt., s. 117nn; L. Stachowiak, Księga Izajasza II-III..., dz. cyt., s. 219nn; G. Witaszek, Pieśni Sługi Jahwe (Iz 42, 1-7; 49, 1-7; 50, 4-9; 52, 13-53, 12), dz. cyt., s. 122nn; Międzynarodowy komentarz do Pisma Świętego, dz. cyt., s. 874; J. Lemański, Cierpienia „stugi Boga” typem zbawczej Pasji Chrystusa, dz. cyt., s. 79nn; R. Rumianek, Prorocy okresu niewoli babilońskiej, dz. cyt., s. 193; D. Adamczyk, Starotestamentalne cytaty w Ewangelii według świętego Mateusza..., dz. cyt., s. 146n; S. Mędala, Dobra Nowina (Wprowadzenie ogólne do Ewangelii synoptycznych), dz. cyt., s. 133n; H. Langkammer, Teologia biblijna Starego i Nowego Testamentu, dz. cyt., s. 190.

${ }^{20}$ Por. J. S. Synowiec, Oto twój król przychodzi..., dz. cyt., s. 160nn; tenże, Prorocy Izraela, ich pisma i nauka, s. 296; T. Brzegowy, Prorocy Izraela, dz. cyt., s. 187; E. Zawiszewski, Księgi proroków..., dz. cyt., s. 119nn; L. Stachowiak, Księga Izajasza II-III..., dz. cyt., s. 219nn; D. Adamczyk, Starotestamentalne cytaty wEwangelii według świętego Mateusza..., dz. cyt., s. 146n.

${ }^{21}$ Por. Międzynarodowy komentarz do Pisma Świętego, dz. cyt., s. 874; C. Stuhlmueller, Deutero-Izajasz (Iz 40-55), [w:] Katolicki komentarzbiblijny, dz. cyt., s. 665;J. Lemański, Cierpienia „stugi Boga” typem zbawczej Pasji Chrystusa, dz. cyt., s. 83nn; R. Rumianek, Prorocy okresu niewoli babilońskiej, dz. cyt., s. 194; H. Langkammer, Teologia biblijna Starego i Nowego Testamentu, dz. cyt., s. 190. 
Od wersetu 53, 4 lud Boży zdaje się już rozumieć sens cierpienia Sługi. Lud ten dostrzega, że cierpi on nie za osobiste grzechy, lecz za grzechy całego ludu. Sługa jest niewinny. Cierpi dobrowolnie. Zawarta jest tu idea cierpienia zastępczego, która została po raz pierwszy tak wyraźnie ujęta. Cierpienie ma tu charakter ściśle soteriologiczny. Niewinny Sługa jest ofiarą zastępczą za grzeszny naród w wymiarze o wiele większym niż ofiary ze zwierząt ${ }^{22}$.

Sługa wykazuje się ogromną cierpliwością podczas wszelkich cierpień. Uwypuklają tę prawdę użyte dwa porównania: baranka prowadzonego na rzeź oraz owcy niemej podczas strzyżenia: „Dręczono Go, lecz sam się dał gnębić, nawet nie otworzył ust swoich. Jak baranek na rzeź prowadzony, jak owca niema wobec strzygących ją, tak On nie otworzył ust swoich" $(53,7)$. Zawarta jest tu również idea dobrowolności ofiary. Sługa bowiem podczas cierpienia nie otworzył ust swoich (por.J 1, 29) ${ }^{23}$.

W pieśni jest również zawarta treść o śmierci Sługi Jahwe. Została mu ona zadana po niesprawiedliwym wyroku (por. Iz 53, 8n). W wersecie 9 czytamy, że został pochowany w grobie między bezbożnymi. Zostaje w ten sposób uwypuklony kontrast pomiędzy pogardliwym pochowaniem Sługi a jego niewinnością. W dalszej części pieśni autor pisze o uwielbieniu Sługi. Nagle w wersetach 10-12 występuje on jako osoba żyjąca, ciesząca się potomstwem, pomyślnością, która otrzyma od Boga tłumy. Sługę czeka specjalna nagroda: „ujrzy potomstwo, dni swe przedłuży” (w. 10). Są to w Starym Testamencie oznaki Bożego błogosławieństwa za życia oraz uwielbienia po śmierci ${ }^{24}$. Zakłada się tu zmartwychwsta-

${ }^{22}$ Por. E. Zawiszewski, Księgi proroków..., dz. cyt., s. 122n; C. Stuhlmueller, DeuteroIzajasz (Iz 40-55), [w:] Katolicki komentarz biblijny, dz. cyt., s. 665;J. Lemański, Cierpienia „sługi Boga" typem zbawczej Pasji Chrystusa, dz. cyt., s. 86n; R. Rumianek, Prorocy okresu niewoli babilońskiej, dz. cyt., s. 194; S. Mędala, Dobra Nowina (Wprowadzenie ogólne do Ewangelii synoptycznych), dz. cyt., s. 135; H. Langkammer, Teologia biblijna Starego i Nowego Testamentu, dz. cyt., s. 190 n.

${ }^{23}$ Por. Międzynarodowy komentarz do Pisma Świętego, dz. cyt., s. 874; J. Lemański, Cierpienia „sługi Boga” typem zbawczej Pasji Chrystusa, dz. cyt., s. 89nn; R. Rumianek, Prorocy okresu niewoli babilońskiej, dz. cyt., s. 194.

${ }^{24}$ Por. E. Beck, Sługa Pański, dz. cyt., kol. 1212; T. Brzegowy, Prorocy Izraela, dz. cyt., s. 189; C. Stuhlmueller, Deutero-Izajasz (Iz 40-55), [w:] Katolicki komentarz biblijny, dz. cyt., s. 666; J. Lemański, Cierpienia "sługi Boga” typem zbawczej Pasji Chrystusa, dz. cyt., s. 86nn; R. Rumianek, Prorocy okresu niewoli babilońskiej, dz. cyt., s. 194n; D. Adamczyk, Starotestamentalne cytaty w Ewangelii według świętego Mateusza..., dz. cyt., s. 147. 
nie Sługi jako początek jego wyniesienia i uszczęśliwienia. Zaznaczono też, że wstawia się za występnymi przed Bogiem ${ }^{25}$. Sługa Jahwe wzrastał jako niepozorny, był wzgardzony, cierpiał, został zabity, a następnie wywyższony przez Boga. Całe to zadanie i sposób, w jaki Sługa je realizuje, odpowiada wyznaniu wiary pierwotnej gminy chrześcijańskiej o Jezusie Chrystusie. Nasuwa to interpretację chrystologiczną tekstów pieśni o Słudze Jahwe w świetle jego śmierci i zmartwychwstania ${ }^{26}$.

Interesujący nas werset 4 zawiera myśl o cierpieniu za innych (zastępczym). Okazuje się, że ów Sługa, którego wykluczono ze społeczności, był najbardziej reprezentatywnym jej przedstawicielem. On wziął na siebie choroby i cierpienia innych. Przez ten jego czyn ludzie wyznają swoje grzechy (por. 53, 5). Zgodnie z tradycyjną koncepcją następstwem grzechów są cierpienia i choroby członków owej mówiącej w tej pieśni społeczności ${ }^{27}$.

Ewangelista odwołuje się do słów z Iz 53, 4 w odniesieniu do Jezusa uzdrawiającego chorych i wyrzucającego duchy nieczyste z opętanych. Ten cytat Mateusz umieszcza we fragmencie Mt 8, 14-17. Czytamy tam: „On wziął na siebie nasze słabości i nosił nasze choroby” (w. 17). Po uleczeniu teściowej Piotra Jezusowi przyprowadzono wielu opętanych i chorych (por. Mt 8, 14-16a). Opętani stanowili specjalną kategorię ludzi wśród chorych przyprowadzanych do Jezusa. Warto jednak zauważyć, że autorzy Nowego Testamentu pojęciem opętania określają również niemal wszystkie choroby psychiczne. Zasadniczo każdą chorobę uważano za naturalne następstwo grzechu. Chory pozostaje we władaniu szatana. Przywrócenie mu zdrowia to uwolnienie go spod władzy szatana ${ }^{28}$.

${ }^{25}$ Por. L. Stachowiak, Księga Izajasza II-III..., dz. cyt., s. 226nn; E. Zawiszewski, Księgi proroków..., dz. cyt., s. 126nn; J. S. Synowiec, Oto twój król przychodzi..., dz. cyt., s. 163nn; tenże, Prorocy Izraela, ich pisma i nauka, dz. cyt., s. 296.

${ }^{26}$ Por. E. Beck, Stuga Pański, dz. cyt., kol. 1212; D. Adamczyk, Starotestamentalne cytaty w Ewangelii według świętego Mateusza..., dz. cyt., s. 147.

${ }^{27}$ Por. L. Stachowiak, Księga Izajasza II-III..., dz. cyt., s. 222; D. Adamczyk, Starotestamentalne cytaty w Ewangelii według świętego Mateusza..., dz. cyt., s. 147.

${ }^{28}$ Por. K. Romaniuk, A. Jankowski, L. Stachowiak, Komentarz praktyczny do Nowego Testamentu, dz. cyt., t. 1, s. 51; S. Fausti, Una comunità legge il Vangelo di Matteo, dz. cyt., t. 1, s. 135nn; D. Adamczyk, Starotestamentalne cytaty w Ewangelii według świętego Mateusza..., dz. cyt., s. 147; C. L. Blomberg, Matthew, [w:] Commentary on the New Testament Use of the Old Testament, dz. cyt., s. 30. 
Wiadomości o cudownych uleczeniach rozeszły się szybko po okolicy. Przychodziło więc wielu ludzi. Jezus uzdrawiał ich swoim wszechmocnym słowem: „On słowem wypędził złe duchy i wszystkich chorych uzdrowil" (w. 16b). W ten sposób, jak podaje Mateusz, urzeczywistniło się proroctwo Deutero-Izajasza: „On wziął na siebie nasze słabości i nosił nasze choroby"29.

Werset 17, w którym Ewangelista cytuje Iz 53, 4, stanowi podsumowanie nie tylko sekcji Mt 8, 1-17, ale całej uzdrowicielskiej działalności Jezusa. Jest to potwierdzenie tezy, że Mateusz wszędzie dopatruje się spełnienia zapowiedzi Starego Testamentu. Także uzdrowienia jako przejaw cudownej działalności Jezusa, są dla autora Ewangelii okazją do odwołania się do proroctwa z Księgi Izajasza ${ }^{30}$. Cytat dotyczy wszystkich cudów dotychczas wspomnianych. Jezus przynosi Izraelowi uzdrowienie i odnowę. Tym samym urzeczywistnia powołanie Izraela jako Sługi Bożego ${ }^{31}$.

Jednak związek tego cytatu z kontekstem ewangelicznym nie jest jasny. Cytat pochodzi z czwartej pieśni o Słudze Jahwe (por. Iz 52, 13-53, 12). W Iz 53, 4 prorok mówi o Słudze Jahwe. Cierpi on za swój lud. Przejmuje na siebie cierpienia i dolegliwości, na jakie zasłużył jego lud przez swoje grzechy. Mateusz, powołując się na Iz 53, 4, chce uzasadnić fakt, że Jezus

${ }^{29}$ Por. A. Sand, Das Evangelium nach Matthäus, dz. cyt., s. 182n; S. Grasso, Il Vangelo di Matteo, dz. cyt., s. 230nn; K. Romaniuk, A. Jankowski, L. Stachowiak, Komentarz praktyczny do Nowego Testamentu, dz. cyt., t. 1, s. 52; D. Adamczyk, Starotestamentalne cytaty w Ewangelii według świętego Mateusza..., dz. cyt., s. 147n.

${ }^{30}$ Por. T. Hergesel, Adoracja Cudotwórcy - Mateuszowa interpretacja cudów Jezusa, „Ruch Biblijny i Liturgiczny" 32 (1979) nr 2-3, s. 114; O. da Spinetoli, Matteo. Il vangelo della chiesa, dz. cyt., s. 260nn; P. R. Gryziec, Według świętego Mateusza. Stary Testament ukryty w Nowym, Kraków 1998, s. 111n.

${ }^{31}$ Por. W. Trilling, Vangelo secondo Matteo, dz. cyt., t. 1, s. 166n; J. Schmid, L'Evangelo secondo Matteo, dz. cyt., s. 221n; J. Schniewind, Il Vangelo secondo Matteo, dz. cyt., s. 199n; R. Fabris, Matteo, dz. cyt., s. 201n; S. Grasso, Il Vangelo di Matteo, dz. cyt., s. 232; J. Radermakers, Lettura pastorale del vangelo di Matteo, dz. cyt., s. 168; S. Fausti, Una comunità legge il Vangelo di Matteo, dz. cyt., t. 1, s. 137n; Międzynarodowy komentarz do Pisma Świętego, dz. cyt., s. 1162; A. Paciorek, Ewangelia według świętego Mateusza, rozdziały 1-13..., dz. cyt., s. 350; D. Adamczyk, Starotestamentalne cytaty w Ewangelii według świętego Mateusza..., dz. cyt., s. 148; C. L. Blomberg, Matthew, [w:] Commentary on the New Testament Use of the old Testament, dz. cyt., s. 30. 
przyszedł z pomocą ludziom cierpiącym, pomimo że pieśń o Słudze Jahwe zapowiada cierpienia wybawiciela ludu ${ }^{32}$.

Ewangelista natomiast nie mówi o cierpieniach Jezusa, lecz o uwolnieniu przez Niego chorych z ich dolegliwości. Luźno powiązany z kontekstem cytat wynika prawdopodobnie z ukrytego rozumowania. Mateusz oddaje tu pewien klimat żydowskiej egzegezy. Chodzi o regułę zwaną gezerah szawah, czyli o taki sposób interpretacji Pisma Świętego, gdzie następuje odwołanie się do tekstów paralelnych, ale nie na zasadzie zgodności treści, tylko ze względu na występowanie tego samego terminu w różnych tekstach i w różnych kontekstach ${ }^{33}$.

Tekst z Iz 53, 4 występuje w kontekście uzdrowienia ze zniszczenia spowodowanego grzechem (por. Iz 53, $5 \mathrm{n}$ i Oz 14, 4) ) $^{34}$. Jezus przyją na siebie karę za grzechy wszystkich. Uzyskał władzę gładzenia grzechów oraz ich następstw, jakimi są choroby i cierpienia. Jednocześnie uzdrawiając ludzi z chorób i dolegliwości fizycznych, Jezus daje dowód, że przyjął na siebie ich grzechy. Działalność terapeutyczna Jezusa była zapowiedzią pełnego duchowego uleczenia ludzi. Miała ona więc od samego początku charakter zbawczy ${ }^{35}$.

W poczet złoczyńców został zaliczony

(Iz 53, 12 i Mk 15, 28; Łk 22, 37)

Słowa: „policzony został pomiędzy przestępców” z Iz 53, 12 zamieszczają dwaj synoptycy: Marek i Łukasz. W Ewangelii Marka słowa

${ }^{32}$ Por. J. S. Synowiec, Oto twój król przychodzi..., dz. cyt., s. 160-175; tenże, Prorocy Izraela, ich pisma i nauka, dz. cyt., s. 294-302; L. Stachowiak, Księga Izajasza II-III..., dz. cyt., s. 216-228; P. R. Gryziec, Według świętego Mateusza. Stary Testament ukryty w Nowym, dz. cyt., s. 112; D. Adamczyk, Starotestamentalne cytaty w Ewangelii według świętego Mateusza..., dz. cyt., s. 148; C.L. Blomberg, Matthew, [w:] Commentary on the New Testament Use of the old Testament, dz. cyt., s. 30nn.

${ }^{33}$ Por. P.R. Gryziec, Wedlug świętego Mateusza. Stary Testament ukryty w Nowym, dz. cyt., s. 112; D. Adamczyk, Starotestamentalne cytaty w Ewangelii według świętego Mateusza..., dz. cyt., s. 148.

${ }^{34}$ Por. C. S. Keener, Komentarz historyczno-kulturowy do Nowego Testamentu, Warszawa 2000, s. 26.

${ }^{35}$ Por. K. Romaniuk, A. Jankowski, L. Stachowiak, Komentarz praktyczny do Nowego Testamentu, dz. cyt., t. 1, s. 52; D. Adamczyk, Starotestamentalne cytaty w Ewangelii wedlug świętego Mateusza..., dz. cyt., s. 148n. 
te znajdują się w ramach perykopy o ukrzyżowaniu Jezusa (Mk 15, 2328), natomiast w Ewangelii Łukasza są one zamieszczone w perykopie o decydującej walce (Łk 22, 35-38).

Słowa te w Księdze Izajasza zawarte zostały w końcowej części czwartej pieśni o Słudze Jahwe. W ramach drugiej wyroczni Jahwe zawartej w tej pieśni sam Bóg mówi o dobrodziejstwach, które przyniesie śmierć Sługi: „Po udrękach swej duszy ujrzy światło i nim się nasyci. Zacny mój Sługa usprawiedliwi wielu, ich nieprawości On sam dźwigać będzie. Dlatego w nagrodę przydzielę Mu tłumy i posiądzie możnych jako zdobycz za to, że siebie na śmierć ofiarował i policzony został pomiędzy przestępców. A On poniósł grzechy wielu i oręduje za przestępcami" (Iz 53, 11n). Cierpliwie znoszone krzywdy ludzkie zostaną wynagrodzone. Podjęty tu zostaje motyw światłości. Światłość (or) jest symbolem radości, szczęścia, chwały i wieczności. Warto zauważyć, że Sługa złożony w grobie nagle ogląda wielką światłość. Oznacza to, że zwyciężył śmierć i powrócił do życia. Poznanie światłości odnosi się tu do całkowitego przeniknięcia Bogiem ${ }^{36}$. Bóg wymienia także dobrodziejstwo usprawiedliwienia wielu. Słowo caddiq (,sprawiedliwy”) zostało użyte najpierw w odniesieniu do Sługi, a następnie w odniesieniu do ludzi. Oznacza to, że Sługa udzieli ludziom tej sprawiedliwości, którą sam posiada. Rozciąga się ona na wielu bez żadnych ograniczeń ${ }^{37}$.

Tekst „policzony został pomiędzy przestępców” (Iz 53, 12) Marek przytacza w wersji: „W poczet złoczyńców został zaliczony” (Mk 15, 28), zaś Łukasz jako: „Zaliczony został do złoczyńców” (Łk 22, 37). Łukasz przytacza te słowa w ramach perykopy o godzinie decydującej walki Jezusa (Łk 22, 35-38). Rozpoczyna się ona od słów Jezusa skierowanych do Apostołów: , «Czy brak wam było czego, kiedy was posyłałem bez trzosa, bez torby i bez sandałów?» Oni odpowiedzieli: «Niczego»" (w. 35). Jezus nawiązuje tu do słów z Łk 10, 4, które odnoszą się do uczniów.

${ }^{36}$ Podobny sens zawarty jest w słowach: „Wszystko przekazał Mi Ojciec mój. Nikt też nie zna Syna, tylko Ojciec, ani Ojca nikt nie zna, tylko Syn i ten, komu Syn zechce objawić" (Mt 11, 27).

${ }^{37}$ Por. E. Zawiszewski, Księgi proroków..., s. 133nn; G. Witaszek, Pieśni Stugi Jahwe (Iz 42,1-7; 49,1-7; 50,4-9; 52,13-53,12), dz. cyt., s. 123n; Międzynarodowy komentarz do Pisma Świętego, dz. cyt., s. 874; J. Lemański, Cierpienia „stugi Boga" typem zbawczej Pasji Chrystusa, dz. cyt., s. 97nn; R. Rumianek, Prorocy okresu niewoli babilońskiej, s. 195; S. Mędala, Dobra Nowina (Wprowadzenie ogólne do Ewangelii synoptycznych), dz. cyt., s. 136. 
Przypomina wyprawę misyjną. Nie pozwolił na nią zabrać nawet niezbędnych rzeczy. Dzięki Bożej Opatrzności gościnność tych, którym uczniowie głosili ewangelię, wystarczyła do zaspokojenia ich potrzeb. Dzięki Bożej troskliwości niczego im nie brakowało z rzeczy koniecznych do codziennego życia ${ }^{38}$.

Teraz sytuacja jest trudniejsza. Nadchodzą czasy Kościoła i sytuacja ulegnie zmianie. Trzeba zatem we wszystko się zaopatrzyć (w. 36). Jezus wylicza, co uczniowie mają ze sobą zabrać. Wskazuje przy tym na pieniądze i torbę podróżną. Trudne do zrozumienia w tym kontekście jest Jezusowe polecenie sprzedania niezbędnego płaszcza i zakupienie miecza. Być może jest to symboliczne określenie powagi sytuacji. Jezus podaje bowiem wolę Bożą, która jest wyrażona słowami: „musi się spełnić na Mnie”. Następnie cytuje słowa z Iz 53, 12 o Słudze Jahwe: „Zaliczony został do złoczyńców" (Łk 22,37a). O powadze sytuacji świadczą również słowa: „To bowiem, co się do Mnie odnosi, dochodzi kresu” (w. 37b). Kończy się ziemskie życie Jezusa. Wraz z tym osiągają cel wszystkie odnoszące się do Niego przepowiednie. Zmiana sytuacji zaznaczy się przez śmierć Jezusa. Apostołowie bardzo mało zrozumieli z tych słów Jezusa. Zapamiętali jedynie wzmiankę o mieczu. Mówią bowiem: „Panie, tu są dwa miecze” (w. 38a). Jezus jednak przerywa rozmowę słowem: „Wystarczy” (w. 38b) ${ }^{39}$.

Treść wypowiedzi Jezusa dotyczy nie tylko rozpoczynającej się właśnie Jego męki. Dotyczy także sytuacji apostołów oraz Kościoła po Jego śmierci. W związku z tym słowo „teraz” (w. 36) nabiera znaczenia głównie dla czasów, w których Łukasz pisał swoją Ewangelię. W omawianej perykopie nie ma wzmianki o zmartwychwstaniu Jezusa. Jest natomiast

${ }^{38}$ Por. F. Gryglewicz, Ewangelia według św. Łukasza. Wstęp - przekład z oryginału-komentarz, Poznań-Warszawa 1974, s. 331n; F. Rienecker, Das Evangelium des Lukas, Wuppertal 1974, s. 506nn; E. Szymanek, Wykład Pisma Świętego Nowego Testamentu, Poznań 1990, s. 160; K. Romaniuk, A. Jankowski, L. Stachowiak, Komentarz praktyczny do Nowego Testamentu, dz. cyt., t. 1, s. 397n; H. Langkammer, Ewangelia według św. Łukasza. Tłumaczenie, wstep i komentarz, Lublin 2005, s. 495n.

${ }^{39}$ Por. F. Gryglewicz, Ewangelia według św. Łukasza..., dz. cyt., s. 332; F. Rienecker, Das Evangelium des Lukas, dz. cyt., s. 507n; E. Szymanek, Wykład Pisma Świętego Nowego Testamentu, dz. cyt., s. 160; K. Romaniuk, A. Jankowski, L. Stachowiak, Komentarz praktyczny do Nowego Testamentu, dz. cyt., t. 1, s. 398; C. S. Keener, Komentarz historyczno-kulturowy do Nowego Testamentu, dz. cyt., s. 176; H.Langkammer, Ewangelia według św. Łukasza..., dz. cyt., s. 496. 
wypowiedź dotycząca miecza. W ten sposób Łukasz wywołuje u czytelnika podobne wrażenie grozy, jaka ogarnęła Apostołów w tym czasie, gdy Jezus wychodził z wieczernika ${ }^{40}$.

Rozpoczynające się czasy Kościoła to czasy niepokoju i wrogości względem wyznawców Chrystusa. Jest to epoka bezwzględnej walki. Stąd wynika potrzeba zabrania ze sobą najpotrzebniejszych rzeczy oraz potrzeba zaopatrzenia się w miecz. Chodzi tu jednak przede wszystkim o uzbrojenie duchowe. Kościół bowiem nie jest „królestwem z tego świata". Bronią wyznawców Chrystusa jest modlitwa, wytrwałość i gotowość pójścia nawet na śmierć. To właśnie tego rodzaju broń należy zdobyć za wszelką cenę. Tej tajemnicy nie pojmowali Apostołowie. Prześladowania Kościoła i wrogość wobec chrześcijan to proste następstwo nienawiści do Chrystusa. To On właśnie będzie uznany za złoczyńcę. Jezus urzeczywistnia proroczą rolę Sługi Jahwe. Słowa z Iz 53, 12 o cierpiącym Słudze Jahwe, na które powołuje się Jezus, oznaczają, że nadaje On swoim cierpieniom ten sam sens. Swoją mękę i śmierć Jezus uważa za zadośćuczynienie za grzechy ludzkości. W tych wydarzeniach Jego życia spełnia się to, co było o Nim zapowiedziane ${ }^{41}$.

Marek cytuje tekst z Iz 53, 12 w perykopie o ukrzyżowaniu (Mk 15, 23-28). Unika w niej rozwlekłości. Podaje, że przybitemu do krzyża Jezusowi podano do picia wino zmieszane z mirrą (w. 23). Taka mieszanina miała właściwości otępiające wrażliwość cierpiącego. Jezus nie przyjmuje tego napoju. Chce do końca wypełnić wolę Ojca w pełnej świadomości. W kolejnym wersecie Marek wskazuje, że gdy już ukrzyżowano Jezusa, żołnierze poprzez losowanie rozdzielili między siebie Jego szaty (w. 24). Następnie podjęta zostaje kwestia godziny śmierci Jezusa: „A była godzina trzecia, gdy Go ukrzyżowali” (w. 25). W rozdziale 15 Marek swoje relacje dzieli chronologicznie na trzygodzinne odcinki (por. 15, 1. 25. 33. 34). Stąd wydaje się, że godzina trzecia u Marka nie jest dokładnym określeniem czasu. Stwierdzenie to jest raczej użyte w znaczeniu szerszym. Chodzi o czas między naszą godziną dziewiątą a południem. Godzina trzecia u Marka posiada także głęboką, symbo-

${ }^{40}$ Por. F. Gryglewicz, Ewangelia według św. Łukasza..., dz. cyt., s. 332.

${ }^{41}$ Por. E. Szymanek, Wykład Pisma Świętego Nowego Testamentu, dz. cyt., s. 160; K. Romaniuk, A. Jankowski, L. Stachowiak, Komentarz praktyczny do Nowego Testamentu, dz. cyt., t. 1, s. 398; H. Langkammer, Ewangelia według św. Łukasza..., dz. cyt., s. 496. 
liczną wymowę teologiczną. Oznacza tu przesilenie się grzechu świata, jego godziny. Marek podaje również, że powód ukrzyżowania brzmiał: „Król Żydowski” (w. 26) ${ }^{42}$.

W końcowej części perykopy o ukrzyżowaniu Jezusa Marek podaje: „Razem z Nim ukrzyżowali dwóch złoczyńców: jednego po prawej, drugiego po lewejJego stronie. Tak wypełniło się słowo Pisma: $W$ poczet złoczyńców został zaliczony" (15, 27n). W ten sposób Marek cytuje słowa z Iz 53, 12. W fakcie, że razem z Jezusem zostali ukrzyżowani dwaj inni złoczyńcy, Marek dostrzega spełnienie się Deutero-Izajaszowego proroctwa. Warto zauważyć, że nie ma tego cytatu w paralelnych perykopach u Mateusza i Łukasza (por. Mt 27, 33-38; Łk 23, 33n). Mateusz, tak bardzo zatroskany o cytowanie Starego Testamentu, którego proroctwa wypełniły się w życiu i działalności Jezusa z Nazaretu, pominął cytat z Iz 53, 12 o zaliczeniu cierpiącego Sługi Jahwe pomiędzy złoczyńców. W Ewangelii Marka Jezus jest Synem Bożym, a równocześnie uniżonym Sługą. Tradycja DeuteroIzajaszowa jest bardziej znana Markowi niż Mateuszowi ${ }^{43}$.

W czwartej pieśni o Słudze Jahwe został przepowiedziany sposób dokonania się zbawienia ludzkości. To Jezus Chrystus dokonał zadośćuczynienia poprzez cierpienie i ekspiacyjną śmierć za grzechy świata. Po zmartwychwstaniu Jezusa Jego słowa i postawa zostały zinterpretowane w perspektywie chrystologicznych myśli o ekspiacyjnej Jego ofierze. To w Jezusie Chrystusie wypełnia się w sposób doskonały i ostateczny wszystko, co w Starym Testamencie zostało zapowiedziane o Słudze Jahwe ${ }^{44}$.

${ }^{42}$ Por. R. Bartnicki, Ewangeliczne opisy męki w aspekcie literackim, teologicznym i kerygmatycznym, [w:] Studia z biblistyki, t. 3: Grzech-odkupienie - miłość, red. J. Łach, Warszawa 1983, s. 188n; K. Romaniuk, A. Jankowski, L. Stachowiak, Komentarz praktyczny do Nowego Testamentu, t. 1, s. 252n; C. S. Keener, Komentarz historyczno-kulturowy do Nowego Testamentu, dz. cyt., s. 119; H. Langkammer, Ewangelia według św. Marka. Tłumaczenie, wstęp i komentarz, Lublin 2004, s. 140n.

${ }^{43}$ Por. H. Langkammer, Ewangelia według św. Marka. Wstęp-przekład zoryginału - komentarz, Poznań-Warszawa 1977, s. 345; E. Szymanek, Wykład Pisma Świętego Nowego Testamentu, dz. cyt., s. 189; P. R. Gryziec, Według świętego Marka, Kraków 1995, s. 136; K. Romaniuk, A. Jankowski, L. Stachowiak, Komentarz praktyczny do Nowego Testamentu, dz. cyt., t. 1, s. 252n; C. S. Keener, Komentarz historyczno-kulturowy do Nowego Testamentu, dz. cyt., s. 119.

${ }^{44}$ Por. H. Langkammer, Teologia biblijna Starego i Nowego Testamentu, dz. cyt., s. 191. 
Dla autorów Ewangelii synoptycznych treść przesłania DeuteroIzajasza o Słudze Jahwe najpełniej historycznie zrealizowała się w osobie Jezusa Chrystusa. W cytowanych fragmentach pieśni o Słudze Jahwe u synoptyków następuje identyfikacja tej zapowiadanej postaci zJezusem Chrystusem. Ewangeliczny kontekst tych cytatów pozwala dostrzec w pieśniach o cierpiącym Słudze Bożym zapowiedź odkupieńczej męki, śmierci i zmartwychwstania Jezusa ${ }^{45}$.

Dopiero jednak w świetle zmartwychwstania Chrystusa Jego świadkowie w nowy sposób zinterpretowali starotestamentalne teksty. Sens działalności Jezusa i wydarzeń paschalnych ukazany został w świetle pieśni o Słudze Jahwe. Synoptycy uwydatnili kwestię odkupienia grzechów przez Jezusa Chrystusa. Tekst o łagodnym Słudze Jahwe z Iz 42, 1-4 zamieszcza tylko Mateusz w perykopie Mt 12, 15-21 po relacji o uzdrowieniach. W świetle Iz 42, 1-4 uwydatniony został motyw uniwersalizmu zbawienia przyniesionego przez Chrystusa jako zapowiadanego, łagodnego i umiłowanego przez Jahwe Sługę ${ }^{46}$. Mateusz ukazuje uniwersalizm królestwa Bożego, a Jezusa jako urzeczywistniającego proroctwo z pierwszej pieśni o Słudze Jahwe.

Tylko Mateusz spośród synoptyków przywołuje również słowa o Słudze obarczonym naszymi słabościami z Iz 53, 4. Odwołuje się do nich w ramach perykopy dotyczącej uleczenia teściowej Piotra oraz licznych uzdrowień (Mt 8, 14-17). W kontekście przywrócenia przez Jezusa zdrowia chorym Mateusz według reguły żydowskiej egzegezy zwanej gezerah szawah dostrzega realizację zapowiedzi z czwartej pieśni o Słudze Jahwe. Uzdrowienia fizyczne jako uwolnienie spod władzy szatana są zapowiedzią pełnego duchowego uleczenia ludzi. Działalność Jezusa od samego początku ma zatem charakter zbawczy.

Motyw wywyższenia w Iz 53, 11n pozwala na dostrzeżenie związku postaci cierpiącego Sługi Jahwe z obrazem Mesjasza jako króla z rodu Dawida ${ }^{47}$. Słowa dotyczące zaliczenia Sługi Jahwe w poczet złoczyńców z Iz 53, 12 znajdują się u Łukasza w perykopie o decydującej walce Jezusa (Łk 22, 35-38), zaś u Marka we fragmencie o ukrzyżowaniu (Mk 15, 23-28).

\footnotetext{
${ }^{45}$ Por. J. Lemański, Cierpienia „sługi Boga” typem zbawczej Pasji Chrystusa, dz. cyt., s. 100n.

${ }^{46}$ Por. S. Mędala, Dobra Nowina (Wprowadzenie ogólne do Ewangelii synoptycznych), dz. cyt., s. 137.

${ }^{47}$ Por. tamże.
} 
Według relacji Łukasza Jezus sam wypowiada te słowa z czwartej pieśni o Słudze Jahwe. Urzeczywistnia w ten sposób proroczą rolę cierpiącego Sługi. Sam Jezus potwierdza, że w wydarzeniach Jego męki i śmierci spełnia się to, co było o Nim zapowiedziane. Marek zaś, przytaczając słowa z Iz 53, 12 w relacji o ukrzyżowaniu Jezusa, również chce uwydatnić fakt realizacji na osobie Jezusa zapowiedzi Deutero-Izajasza. W ten sposób Jezus Chrystus dokonuje zadośćuczynienia za grzechy ludzkości.

Kielce

DARIUSZ ADAMCZYK

\section{Słowa kluczowe}

Sługa Jahwe, Jezus Chrystus, Ewangelie synoptyczne, Deutero-Izajasz

\section{Summary}

Quotations from the songs about Servant

of Yahwe in Synoptic Gospels

We don't get to know from Isaiah's songs, who is the Servant of Yahwe. In Synoptic Gospels quotations are contained from the first and fourth songs about the Servant of Yahweh. Synopticians interpreted in a new way Old Testament texts in light of Christs resurrection. They see prophetic announcement and the same type of Jesus Christ, Messiah and Saviour in Isaiah's Servant. In Jesus Christ is filled out in a perfect and final way everything the Old Testament has announced about the Servant of Yahweh. The evangelical context of these quotations allows one to see in the suffering of the Servant of God, announcement of the redemptive fatigue, death and resurrection of Jesus.

\section{Keywords}

Servant of Yahve, Jesus Christ, Synoptic Gospels, Deutero-Isaiah 